\title{
From stage to street: The \#EndSARS protests and the prospects of street theatre
}

\author{
Cindy Anene Ezeugwu'1 Oguejiofor V. Omeje², Ikechukwu Erojikwe', Uche- Chinemere \\ Nwaozuzu${ }^{1}$ Ndubuisi Nnanna ${ }^{1}$ \\ University of Nigeria, Nsukka \\ 'Department of Theatre and Film Studies. \\ ${ }^{2}$ Humanities Unit, School of General Studies.
}

\begin{abstract}
Globally, the issues of extrajudicial killings are on the increase. From racial killings in the West to wanton human rights violations in Africa, the pains are the same. Thus, protests have always been a channel employed by many including activists, labour and union leaders among others, to press home grievances and demands against unfavourable policies and social malaise. This paper draws attention to how youths in Nigeria utilised the physical space to spark a protest, in October 2020. Notable actors, musicians, comedians, activists and the international community in their numbers, moved to the streets in defiance of security orders to protest against police brutality and harassment. In view of the outcome of the protest, which was later hijacked by hoodlums, the paper examines a non-violent alternative which can be used to address societal issues. It is in this context that the paper examined the role of theatre as a tool for activism, advocacy and communication with specific reference to street theatre, a type of improvised street drama performance that addresses unfavourable socio-political and cultural issues.
\end{abstract}


The data for the study were obtained mainly from the internet, print media, observations, interviews and literary works. For its methodology, the study utilises the popular theatre approach. The study concludes that street theatre has a major role to play in addressing sociopolitical issues without resorting to violence.

Keywords: \#Endsars, Protest, Police, Youths, Street Theatre, SARS, Brutality, Government

\section{Introduction}

Solomon Ibrahim Hari submits that "in Nigeria, as in most of the developing world, citizens are often confronted with myriad threats and challenges about their wellbeing and survival. These include poverty, high rates of unemployment, violence, deprivation of resources, lack of opportunity, marginalization and the denial and suppression of basic rights and freedom" (1).Toeing the same line, several people, including notable writers like Chinua Achebe, Wole Soyinka, Femi Osofisan, Tunde Fatunde, Emeka Nwabueze, Rasaki Ojo Bakare, and Esiaba Irobi among others, have attempted to locate Nigeria's problems on quality or absence of quality leadership and management. Leadership is critical, whether in the family, Town Union, Age Grade, the community or nation. The success of a group or a nation depends largely on the capability of the leadership and the nature of the policies they make. Even economists like Adam Smith have agreed that "the progress of a nation no longer depends on the wealth or natural endowment of the nation, but on the core values espoused by that nation, which includes responsibility, transparency, honesty, accountability and hard work" (142). Thus, it is the responsibility of leaders to drive these core values, especially by the examples they set.

Many people in Nigeria have suffered so much loss and untold hardship due largely to the activities of the dreaded Special Anti-Robbery Squad (SARS), a unit of the Nigeria Police that was created in late 1992 to tackle crimes that are related to robbery, theft, kidnapping and possession of fire arms among others (Chow, 2020 October); but which later metamorphosed into a full blown brutal squad that specialises in harassing, maiming and in some cases, engage in extrajudicial killing of people. "The losses are varied, including 
human lives and property" (Aljazeera, 2020). As it is usual with the media, the reports of these incessant killings are mostly under-reported; and in instances where the cases are pushed to the media, it is usually followed by rebuttal and in some cases retraction. Several attempts to draw government's attention to these human rights violations have yielded little or no result. Thus, this led to a nationwide protest that was later commandeered by hoodlums into a violent protest. In light of the above, this paper examines the role of street theatre and its potentials for social activism and advocacy, aimed at addressing socio-political issues in Nigeria.

\section{Perspectives on \#EndSARS protests}

Protests have been variously defined to mean public disapproval, objection or disagreement over an ideology, action, activities or policy with a view to draw attention to its negative impacts, effect a change, modify a policy, influence public opinion, or overhaul a policy that is detrimental to the citizens. A protest can assume any form ranging from picketing, rally, walks, carrying of placards, sharing of leaflets, to vigil and sit-in, among others. Thus, Thomas Ratliff and Lori Hall categorized protest into six broad types namely movement in space, Civil disobedience, Collective violence and threats, Solemnity and the sacred, Institutional and conventional protest, and Literal, symbolic, aesthetic and sensory protest. The last category which is the literal, symbolic, aesthetic, and sensory protest captures the type which emphasizes the model of the street theatre. Tom Bieling explains it as an "artistic, dramaturgical and symbolic displays (street theater, dancing, etc.) including use of images, objects, graphic art, musical performances, or vocal/auditory exhibitions (speechmaking, chanting, etc"(46).

As Oludamola, Adebowale avers, Nigeria has a long history of protests, beginning from the "1929 Aba Women protest against the British colonial administration, in the present-day Eastern and South-South regions, the Coal miners' strike in Enugu in 1949 to the Abeokuta protest in the 40s, the 1953 Kano riot, Maitasine protest in the 80s, Jos riots of 2008 and 2010, Abuja bus crash protests, among others, to a more recent Bring Back Our Girls (BBOG) protest" (9).

Thus, more recently, Nigeria witnessed the \#EndSARS protests that globally swept across countries and whose first wave started in 2017, as a social media hashtag against police brutality and 
extrajudicial killings of Nigerians. ages of 18 and 30 caught by SARS mostly Premium Times newspaper, added that;

The \#EndSARS was first twitted in 2017, by a group of activists led by Segun Awosanya as a call to disband the Special Anti-Robbery Squad (SARS), a unit of the Nigeria Police Force and metamorphosed into a physical protest starting from the $8^{\text {th }}$ of October 2020, at the Lekki tollgate, Lagos (24 $4^{\text {th }}$ October:2020).

"From being a section carved out from the Police Force to protect Nigerians, the Special Anti-Robbery Squad (SARS) transformed itself into a hydra-headed monster that acted without recourse to the law "(personal Interview). Adding to this, Amnesty International (Al) report of 2020 stated that the "extrajudicial killings by SARS started between 2001 and 2002" (np). For decades, the Nigeria Police Force has had a long history of violence and abuse of human rights but SARS Unit of the Police, took police brutality and extrajudicial killing to an unimaginable height. Often times, they tried to rationalize their abuse of power to the spate of crime going on in Nigeria.

Over time, the Nigerian SARS also started the profiling of youths on the street. Confirming this, CNN News on line, revealed that "many youths between the with dyed hair or dreadlock hair, and/or spotting a neck chain, ring, and adorning a distress jean and T-shirt are presumed potential cybercrime culprit. Often times, these young men are illegally detained, tortured, and ordered to pay substantial sums of money before they are released" (October24: 2020). Often times, the trumped up allegations against the victims are unfounded, and in cases where some of them are not able to meet up with the amount requested, they are brutally harassed, intimidated and in some cases killed. Furthermore, their gadgets like phone, ear plugs, laptops and ipads are forcefully taken away from them. Many of the young men and women have been implicated in crimes they knew nothing about. Repeatedly, some of the SARS officers go as far as demanding ransoms from families and friends of suspects in exchange for their lives. All these were the remote causes which later gave vent to the \#EndSARS protests.

After several decades of enduring extrajudicial killings, torture, extortion, unlawful arrest and detention of many under the watchful eyes of unconcerned and non-responsive government, some Nigerians not minding their political affiliations, ethnic groups, religious 
inclination, gender or status, joined forces together to fight against perceived injustices by the security agency and the Nigerian government. They fought against state merchants who tried to hijack their coordinated activities, and attempt to rearrange Nigeria into a country where justice will exist both in the National Anthem and in the treatment of its citizens, irrespective of class or status.

It is on record that many Nigerians, especially the youths are unemployed, and in their bid to find a means of livelihood, many of them engage in different kinds of trade and transactions, the internet inclusive, in order to help both ends meet. Though some of them run foul of the law, but the harassments/punishments meted out to the victims are most of the time, not commensurate to the offense committed. Through the use of the internet, many of them have found new ways of making a living, as Sanya Osha admits:

Young Nigerians often navigate harmful stereotypes while using the internet. An example of such stereotypes is that they are engaging in internet fraud. But though federal and state governments remain the largest employer of labour, many Nigerians remain formally unemployed

(3).

Lending his voice to the unemployment rate in Nigeria, Yomi Kazeem stated in Quartz Africa that, "one of every two Nigerians in the labour force (or 21.7 million Nigerians) is unemployed. Unemployment rate has tripled during President Muhammadu Buhari's administration" (2). With the evergrowing influence of information technology and social media, Nigerian youths began to create jobs for themselves as on line marketing strategists, content creators, IT experts, brand ambassadors, social media influencers and networking officers.

Gene (2021, February), explained that;

the brutal murder of Ifeoma Abugu in September 2020 in Abuja and a viral tweet by $@$ AfricaOfficial2 reported that Special Anti-Robbery Squad officers in Nigeria had shot and killed a young boy and left his body by the side of the road in Ughelli, Delta State in October, sparked off a protest in Abuja in 
October 2020, and spread into the global space (np).

These extrajudicial killings were the immediate cause which fueled the second wave of the \#EndSARS protests in addition to many other atrocious activities of the defunct SARS. Despite all the efforts by the youths to stay off crime, the SARS operatives persisted in their inhuman treatments; and as Osha added, "almost everyone had a SARS horror story to tell and it all got too much when the bubble burst in a deluge of national protests in October 2020"(3). As such, the \#EndSARS protest was the opportunity needed to highlight and expose harmful stereotypes that young people face, which had emboldened SARS operatives to intimidate, criminalise and brutalise Nigerian youths.

Gene (2021 February) report of 2020 added that "the \#EndSARS movement spread beyond Nigerian borders, leading to solidarity protests in different parts of the world" (np). It grew to become a global movement, which set out to challenge perceived injustices against Nigerians by the security agencies and by extension, bad governance. According to a report by Aljazeera News Cable, "many people in countries like Canada, America, Holland, France, Ireland, South Africa and Germany among others took to the streets in their numbers to add their voice on the call to disband SARS" (Aljazeera News, November:2020).

During the peaceful protests, the Nigerian government, instead of paying attention to the root cause of the protests, responded with force, violence, bloodshed, indiscriminate arrests, imprisonment, and freezing of the conveners' accounts. At the end of the day, the efforts of the real \#EndSARS protesters was truncated as hoodlums and criminals hijacked the protests which led to over two weeks of breaking into stores/shops, looting of valuable properties, gruesome murder of both police officers and civilians, as well as burning down of police stations and destruction of government and individual property, among others (Premium Times, 24 October: 2020). The long awaited speech by President Muhammadu Buhari did not help matters as it only aggravated the issue at stake. The government only changed the name of SARS to SWAT an action which can be likened to 'jumping from frying pan to fire'. It is so because as at the last count, extrajudicial killings, extortion, harassment and intimidation of all kinds are still going on in their numbers in the country. 
In view of the challenges highlighted above, this study examined an alternative method which can be adopted to raise concern and draw the attention of the government to the fact that nothing has changed after the protest despite wearing the SARS unit a new garb. Arising from this, the researchers are of the view that Street Theatre as the name imply is a fitting template which can be used as a channel for conflict management.

In the words of Edith Hamilton, "the way a nation goes, whether that of the mind or of spirit is decisive in its effect upon arts" (38). It is axiomatic that police brutality is a challenge created by the security agencies and it will require human beings to resolve the challenges arising from the menace in the society. The need to find a lasting solution to police brutality in Nigeria has become crucial, especially as the situation in not abating. As the debate on its impact intensifies, the researchers are of the view that theatre has a role to play in finding a solution to the problems. As an effective communication tool, theatre has severally been involved in creating awareness on societal issues while at the same time engaging the powers that be on the need to bring an end to senseless killings and intimidations.
There is a general belief in Nigeria that police brutality has reached a crisis level and constitutes a time bomb waiting to explode if it is not urgently addressed. This is as a result of unmitigated frustrations, starvation, bad governance and unemployment in the country which are adding significant stress on the citizens. Through the ages, theatre has continued to capture and mirror events in the society; and one issue that has continued to make headlines in newspapers, social and communication media presently is the issue of police brutality which was in the front burner during the recent \#EndSARS protests. In line with Hamilton's view above, it is expected that theatre could mirror the challenges arising from the aftermath of the protest and be able to find alternative ways of channelling people's anger and concerns to the appropriate quarters without any loss of lives and property.

Before now, people, especially the government, tend to look down on theatre as a viable instrument for conflict resolution and management. Confirming this, Raphael Ogu maintains that:

The medium of theatre, like other art forms have never received any considerable measure of 
attention from the them. Enunciating the relationship governments and its between theatre and the society, Alvin agencies, perhaps because it is considered as unserious business and a time waster and therefore not capable of generating any form of development both for the individual and for the society (5).

Going further to counter this view by people and the government, Ogu maintains that the functions and manifestations of the "theatre in our society today has taken a very radical trend, such that the entertainment value has received some kind of de-emphasis. Its role now is to serve a more constructive purpose, one that will contribute to the social and revolutionary change in the society" (5).

Stanley Obuh, explaining the relevance of theatre as an instrument for change, averred that "one of the agents of socio political change is theatre" (138). In a situation where intimidation, exploitation and harassment thrive, it becomes imperative to seek for alternate ways of addressing such issues. Thus, theatre comes to mind as one of the arms of art that mirrors everyday experiences of the society with a view to proffer solutions to Schnupp notes that, "the closely aligned ties that exist between theatre and life, contributes to the notion that theatre is a model of the world. In each realm, events and incidences occur, develop and are resolved" (4). In view of the above, it may appear impossible to try to separate theatre from life as lived and imagined, from things that affect, influence or oppress it. Theatre provides the society, with the opportunities to express their concerns and seek for answers to their diverse problems. In echoing the role of the theatre artist, Ayo Akinwale explains that, "the theatre artist must create for the people, he is made by the people and his works must of necessity be a reflection of his people" (37).

\section{An overview of theatre as a medium for advocacy}

Theatre can be viewed as an act of communication and advocacy. It is a medium that can be used to address challenges, raise awareness, and call for a change in approaches and effect desired changes in the society through enacting real or imagined events. It has remained a viable instrument for education and it is one of the efficient weapons of emancipation globally. Theatre experience 
can take place in a building, a street, market place, village square, crowded areas, schools and churches among other places. As Egwugwu Illah avers, "as much as theatre educates, it also has the capacity to provoke thought or action about significant issues in the society" (4).

Arising from the aftermath of the \#EndSARS protests, which ended in so much bloodshed, loss of lives and destruction of property by hoodlums, the researchers are of the view that Nigerian minds should be re-channelled towards advocacy (instead of protest) and theatre for national development through the Street Theatre approach. Dramatist like Arthur Miller is known to have projected the tragic situation of the common man in his work, Tragedy and the Common Man. His theory was later developed by Augusto Boal, who removed theatre from the enclosure of conventional stage and placed it in the hands of the masses. Explaining the role that theatre can play in advancing the plight of the people, Ngugi Wa Thiong'O states that, "theatre is a weapon and it is the people who should use it" (6). In Nigeria, notable theatre practitioners like Hubert Ogunde, Duro Ladipo and Duro Oni are known to have used popular theatre to address the issues of colonialism, oppression and discrimination, among others. In light of this, theatre has evolved over the years to become an advocacy tool for activism, emancipation and liberation of the oppressed. It mirrors the society with a view to change lives, attitudes, approaches and practices that maybe detrimental to the individual and the society at large, SARS brutality inclusive. Theatre has never shied away from difficult challenges irrespective of how enormous such issues may appear. Over the years, theatre is known to have resolved tasking issues which border on social injustice and abuses with drama.

\section{An overview of street theatre and its potentials for change}

Street Theatre emerged in early $20^{\text {th }}$ century in India, as a tool to liberate workers against the establishment during their anti-colonial struggle. Thus, it has grown over the years to tackle broader issues like oppression, injustice and human rights abuses among others. It is more participatory in approach; thus, it allows everyone to take part (participation/mobilisation) in an activity (problem solving) that concerns the community (advocacy/sensitisation).

Street Theatre is performed in open forums at no cost, it is improvisational and anyone can take part in it; the audiences are 
allowed to be part of it at no cost. Ankita Banerjee posits that;

Street theatre as a distinctive form of performing arts, facilitates the process of social change by using the visual forms, expressive representation, easy reception, language of the people and makes way for participatory communication (5).

Adding another dimension to the features of Street Theatre, Jan Cohen-Cruz defined it as an "expression of revolutionary political and nationalist movement that not only entertain its audiences, but has a deep rooted role to play in social change" (12). Toeing the same line, Safdar Hashim, a theatre activist, views Street Theatre as a "tool to spread political ideology, especially to propagate communism and draw the masses of people into the antigovernment struggle" (8). Submitting a broader view of Street Theatre, the researchers maintain that it is a form of group drama that is performed outdoor, mainly on the streets, markets, schools, railway stations and slums, where a group of artists can interact with a broad section of audiences directly for the purpose of not merely entertainment but to trigger activism.
The researchers added that Street Theatre is merely driven by the need to disseminate messages of hope, development, rescue, social emancipation and political reform, and it makes use of colloquial languages that are embellished with songs, dance and chants; and involves minimum use of props and costume without theatrical set pieces, as its basic features. It is highly mobile as the performers can move from street to street with ease with no walls to barricade them from the audience. Here, the actors do not wait for the audience to come to them as they do in conventional theatre, the performance is carried to the audience making it more participatory as it reaches wider audience in the language that they understand as it is usually communitybased and addresses issues and challenges confronting the society.

John P. McHale refers to a connection between Street Theatre and guerrilla theatre and stresses its effectiveness for advocacy communication. He posits that;

Non-conventional communicative form such as Street Theatre is an available tool for advocacy... it is extremely effective just like guerrilla theatre, because of its tactics. In this context, we do 
not forewarn or announce our performances beforehand, because anyone who wants to stop the performance would be able to do so if they are given prior notice (6).

To this end, therefore, the researchers are of the view that Street Theatre remains a veritable tool to address burning issues without destruction of property and loss of lives. This view is captured by Friere Paulo thus: "Theatre relates to society by way of effecting, explaining and contributing to its stabilisation of values and generally supplying it with the necessary guides" (13).

It is hardly the case, that theatre practitioners have been neglecting the issues of police brutality, neither are they unaware of the links between police harassments, government ineptitude and unaccountability and human rights violations going on in the country. The researchers contend that such awareness have been front and centre in the works of several dramatists in the likes of Wole Soyinka's Kongi's Harvest, Ola Rotimi's If ...A Tragedy of the Ruled and Hopes of the Living Dead, Femi Osofisan's Once Upon Four Robbers and Morountodun, Ahmed Yerima's Pari, Emeka Nwabueze's $A$ Parliament of Vultures and Esiaba Irobi's
Nwokedi, among others. Through their works, these playwrights have attempted to mirror human rights violations, bad governance and the plight of the masses in Nigeria.

Since theatre can be viewed as a mirror that portrays societal issues, theatre artists are therefore not left out in the quest to draw attention to police brutality and human rights abuses in Nigeria. As creative artists and researchers, theatre artists serve as links between the people, the establishments and the security agencies creatively involving advocacy through theatre performances to bring solutions to societal problems. They serve as town criers and information outlets, sensitising the people on bad governance and police brutality and all these will be emanating through the portal of stage performances, films and movies, popular theatre, especially the Street Theatre.

\section{Conclusion}

\#EndSARS protests gained so much momentum when it started physically from8th to 21st of October, 2020 and many people applauded the peaceful manner that the protesters adopted in many of the states in Nigeria in channeling their grievances. The protest had no defined leaders or arrowheads, this 
was done purposely to help ward off politicians and corrupt office holders from infiltrating the group, but some people in the likes of AishaYusuf, Dj Switch, Kayode Oyero, Folarin Falana, Debo Adeboye and Henry Shield among others played major roles in sustaining the protest. According to a newspaper report, " the bank accounts of people like Sadat Bibi, Bassey Victor Israel, Ezenwanyi Uhuo, Bolatito Oduala and many others were frozen on the order of the apex bank-Central Bank of Nigeria on the allegation that their accounts were used to fund the protest" (Punch Newspapers, 10 November: 2020). Initially, many people projected that the protest will lead to the beginning of a new dawn and an avenue to correct many of the ills in the society like corruption and human rights violations but after about three weeks of sustaining the tempo of peaceful protest, hoodlums hijacked the protest which led to massive destructions, loss of lives and property among others. Premium Times reported that "On the night of 20th October 2020, members of the Nigerian Army stormed the Lekki toll gate in Lagos state and opened fire on peaceful and unarmed End SARS protesters" (October 21, 2020). Many of the protesters were killed, while many were reported as either missing or hospitalized. After one month of denials, blames and counter blames between the Lagos state governor Mr. Babajide SanwoOlu and the Nigerian Army about who authorised the shooting incidence at Lekki, on the $26^{\text {th }}$ of October, 2020, the Nigerian army in response to a CNN footage of the Lekki shooting, admitted at the ongoing Lagos Judiciary panel of inquiry that was set up by the governor that it deployed some of its personnel to the Lekki toll gate with both live and blank bullets to disperse the protesters (CNN online news, November 19:2020 ). In addition to the evidence provided by CNN footages, Nigerian disc jockey Obianuju Udeh popularly known as DJ Switch live streamed video of the shooting at Lekki toll gate which she posted on her Instagram account also helped to validate the claim that the army shot at the unarmed protesters. Many other eye witness accounts also affirmed that indeed the protesters at Lekki toll gate were fired at with live ammunitions and not rubber bullet as initially claimed by the Nigerian Army.

It is in the light of these sad incidences that the researchers re-evaluated the gains and losses of the protest and sought for an alternative type of approach that can be adopted in addressing sociopolitical issues in Nigeria without the 
application of violence and destruction. Thus, a fitting template in the mold of theatre is recommended.Theatre has the power to appeal to emotions and capture social, political and historical conditions; its relevance in conflict resolution and management cannot be overemphasised. The history of theatre as an expression of cultural resistance against obnoxious policies and norms reverberates through the ages. Popular Theatre, Street Theatre, Theatre for Development (TfD), Guerrilla Theatre and Agip (Agitation) Prop Theatre, among others, have been applied at different times and situations either to raise awareness against despotic situations, to call out the establishment against bad governance or to unite the masses for action against oppressive security agencies.

Theatre in Nigeria too has a long history of socio-political consciousness. Chinua Achebe, Wole Soyinka, Femi Osofisan, Emeka Nwabueze, Rasaki Ojo Bakare and Sam Ukala, among others, remain some of Nigeria's most popular playwrights and authors who have used their works to address the challenges associated with bad governance, unaccountability and extrajudicial killings. The study suggests that there is a general belief in Nigeria that police brutality has reached a crisis level and consequently, constitutes a time bomb waiting to explode. This assumption is as a result of unmitigated frustrations, human rights violations, poverty and unemployment ravaging the country which is adding significant stress on the lives of the citizens.

What Achebe and others envisioned many years ago about Nigeria have continued to be the fundamental problem of the country, which many government regimes have failed to address till date. Achebe amplified this point by insisting through his works namely No Longer at Ease, Man of the People, Anthills of the Savannah and There Was a Country that Nigeria lacked and has continued to lack a charismatic leader that could understand the minds of her citizens in pivoting the affairs of the country in a right direction. In Achebe's words, "there is nothing wrong with the people of Nigeria, but the problem is that wrong people are placed in the wrong places"(23).

This paper highlights the inept behaviours of political leaders and security agencies in Nigeria by calling for an end to their corrupt and obnoxious attitudes that enslaves the citizens, especially the youths. It also calls for an end to street profiling of Nigerians, especially the youths, police intimidation and human 
rights violation. A situation which led to the \#EndSARS protests that witnessed lots of destruction of both lives and property as a result of the fact that it was hijacked by hoodlums at some point.

The Federal Government has accepted all the five demands placed before it by Nigerian youths; which include Immediate release of all arrested protesters, justice for all deceased victims of police brutality and appropriate compensations for all their families, Setting up of independent body to oversee the investigation and prosecution of all report of police misconducts, In line with the new police act, psychological evaluation and retraining of all disbanded SARS officers is required before they can be redeployed and finally, Increase in Police salary so that they can effectively protect lives and property of citizens. As at August 2021, most of the demands are yet to be implemented. The Federal Government has dissolved the Special Anti-Robbery Squad and established a Special Weapons and Tactical Unit (SWAT), which many people claim lack originality; thus, it is not yet uhuru for the masses. Acceding to the demands, many state governments set up judicial panels to hear complaints by members of the public in that respect. The panels are chaired by retired high court judges and have members from civil society groups, the police, the National Human Rights Commission (NHRC) and youth groups ((Premium Times, 2021). This type of specialized panel is a fitting example of what Tendaishe Tiou recommended in his paper titled Revisiting Peace and Reconciliation in Africa: Taking Stock of African Truth Commissions' Progress and Challenges Thus Far where he stated that "...truth commissions are important institutions which can be established in both conflict and post conflict periods to ensure that widespread or systemic human rights violations are accounted for and do not recur" (1). The panels in various states are still investigating the human right abuses and violations and it is hoped that at the end of its investigations, those who are found guilty of human rights violations will be made to face the law.

The study therefore, calls for a change in strategy and recommends the use of street theatre (an outdoor theatre presentations in open and public space which usually seeks to address national, state or regional concerns in the language of the people) as an alternative to protests and riot in addressing injustices. The paper suggests that the use of Street Theatre as a preferred alternative to street protest in 
engaging the establishment about societal issues will bring aggrieved parties to the negotiating table without any violence. 


\section{Reference}

Achebe, Chinua. The Trouble with Nigeria. Enugu: Fourth Dimension Pub., 1998.

Adebowale, Oludamola."History of Protests in Nigeria: Reactions and Consequences". The Guardian Life, 25 $5^{\text {th }}$ October, 2020. Accessed $9^{\text {th }}$ August, 2021.

Akinwale, Ayo. "The Theatre and the Nigeria's New Democratic Environment: A Sociological Overview". In Ahmed Yerima and Ayo Akinwale (Eds.), Theatre and Democracy in Nigeria. Ibadan: Kraft Books Ltd, 2002.

Aljazeera. "We need to live': Young Nigerians on why they are protesting" https://www.weneed-to-live-young-nigerians-on-why-they-are-protesting/.com. Accessed $7^{\text {th }}$ August, 2021.

Amnesty International. "Nigeria: \#EndSARS: Investigate Killings of Protesters". Amnesty International Report.26 0ct.2020. Accessed $3^{\text {rd March, }}$ 2021.https:/www/world.org/pdfid/3f15241e4.pdf

Banerjee, Ankita. "Evaluating the Role of Street Theatre for Social Communication". Article-15, Global Media Journal-Indian Edition, 4.2 (2013): 18-26.

Bieling, Tom. "Design and Activism: Perspectives on Design as Activism and Activism as Design". Mimesis: Milano Ltd., 2019.

Chow, R. Andrew (2020, October 28). "The Nigerian Government Has Pledged to \#EndSARS and Reform the Police. This Isn't the First Time They've Made That Promise". Time https://time.com/andrew-r-chow-the-nigerian-governmenthas- pledged-to- endsars-and-reform-the-police-this-isnt-the-first-timethey-made-that- $\quad$ promise/.com. Accessed $6^{\text {th }}$ August, 2021.

CNN on line News. "How a bloody night of bullets quashed a young protest movement". https://www.cnn.com/Africa/2020/11/18/Africa/lagos-nigeria-lekkitollgate- 19 November, 2020. Accessed 8 August, 2021.

Cohen-Cruz, J. (1998). Radical Street Performance: An International Anthology. New York: Routledge, 1998.

Freire, Paulo. Pedagogy of the Oppressed. New York: Penguin Books, 1992. 
Gene, Dominique (2021). "A Movement, not a Moment: How Nigeria's \#EndSARS continues to influence the World". The Charlatan Independent Weekly.13ih, February, 2021.

Accessed, July 12, 2021.

Hamilton, Edith. The Greek Way. New York: Avon Books, 1973.

Hari,Solomon Ibrahim. "The Evolution of Social Protest in Nigeria: The Role of Social Media in the "\#0ccupyNigeria Protest". International Journal of Humanities and SocialScience Invention. Vol. 3, Issue 9 (2014): 33-39.

Hashmi, Safdar."Murder Case: Sequence of Events." Times of India. Retrieved 2 Apr. 2021.http://articles.timesofindia.indiatimes.com/05/india/27183374_1_safdarhashmi-ghaziabad-city-board-ram-bahadur

Illah, Egwugwu J. Theatre Politics and Social Consciousness in Nigeria. Jos: Leadership Production Press, 2002.

Kazeem, Yomi. "Nigeria's Unemployment Rate". 14Aug. 2020. Accessed 10 April, 2021.Quartz Africa. https://www.unemploymentinnigeriaquartzafrica.com

McHale, John P. Communicating for Change: Strategies of Social and Political Advocates.Lanham,UK: Rowman\& Littlefield, 2004.

Obasi, Obiorah. "On \#EndSARS Protest". Personal interview. 10 1 th May, 2012.

Obuh, Stanley. Mobilisation: A Critical Analysis of Some MAMSER Drama Programmes in Nigeria. Ibadan: Caltop Publishers Ltd, 1992.

Ogu, Raphael. The Medium of Theatre as an Alternative to Conflict Resolution Mechanism: A Case Study for the Niger Delta. Nsukka: University of Nigeria Press, 2009.

Osha, Sanya. "How Music Captured the Frustrations of Young Nigerians." 3 Mar. 2021.Accessed 12 Mar. 2021.Africa Portal.com.

Oyero, Kayode. "\#EndSARS:Its unfair CNB Froze my Account, says Lagos Panel Member".Punch News Papers, 10 November, 2020.

Oyerinde, Peter. "ANALYSIS: \#EndSARS: Five Months after, is the Nigerian Govt Meeting Protesters' Demands". Premium Times April 28 ${ }^{\text {th }}, 2021$. 
Ratliff, Thomas, and Lori Hall. Practicing the Art of Dissent: Toward a Typology of Protest Activity in the United States. Journal of Humanity and Science. Vol. 38 (3) (2014):268-294.

Schnupp, Alvin. Theatre: A Model of the World. California: Kendall/Hall Publishing Co., 1995.

Smith, Adam. "An Inquiry into the Nature and Causes of the Wealth of Nations". Oxford: Oxford University Press (reprinted) 2008.

Tiou Tendaishe. "Revisiting Peace and Reconciliation in Africa: Taking Stock of African Truth Commissions' Progress and Challenges Thus Far". Ikenga International Journal of Institute of African Studies, Vol. 21 No.1 \& 2 (2020): 1-12.

Wa Thiong'0, Ngugi. Decolonising the Mind: The Politics of Language in African Literature. New York: Twayne Publishers, 1998. 